\title{
AQUA-motion domain and metaphorization patterns in European Portuguese: AQUA-motion metaphor in AERO-motion and abstract domains
}

\author{
O domínio da deslocação em líquidos (AQUA-motion) e padrões de metaforização em
}

Português Europeu: a metáfora de deslocação em líquidos no domínio da deslocação no

ar (AERO-motion) e no domínio abstrato

\section{Hanna Jakubowicz Batoréo}

Universidade Aberta - Lisboa - Portugal

\begin{abstract}
The AQUA-motion verbs - as studied by Majsak \& Rahilina 2003 and 2007, Lander, Majsak \& Rahilina [2005] 2008, 2012 and 2013, and Divjak \& Lemmens 2007, and in European Portuguese (EP) by Batoréo, 2007, 2008, 2009; Batoréo et al., 2007; Casadinho, 2007 - allow typically metaphorical uses, which we postulate can be organized in patterns. Our study shows that in European Portuguese there are two metaphorization patterns to be observed: (i) AQUA-motion metaphor in AERO-motion domain and (ii) AQUA-motion metaphor in abstract domain (e.g. abundance, arts, politics, etc.). In the first case, where the target domain of the metaphorization is the air, in EP we navigate through a crowd or we float in a waltz, whereas in the second, where it is abstract, we swim in money or in blood, and politicians navigate at sea or face floating currency in finances. In the present paper we survey the EP verbs of AQUA-motion metaphors in non-elicited data from electronically available language corpora (cf. Linguateca). In some cases comparisons are made with typologically diferent languages (as, e.g. Polish, cf. Prokofjeva's 2007, Batoréo 2009).
\end{abstract}

Keywords: AQUA-motion. AERO-motion. European Portuguese. Language Typology. Metaphorization. Metaphorical patterns.

Resumo: O grupo de verbos conhecido em Linguística Cognitiva do ponto de vista tipológico como verbos AQUA-motion, isto é, os verbos que designam movimento desenvolvido prototipicamente em água (e com a extensão semântica para qualquer outro líquido) foram exaustivamente estudados por Majsak \& Rahilina 2003 e 2007, Lander, Majsak \& Rahilina [2005] 2008, 2012 e 2013, assim como por Divjak \& Lemmens 2007. Em Português Europeu a temática foi desenvolvida por Batoréo, 2007, 2008, 2009; Batoréo et al., 2007; Casadinho, 2007. Este grupo de verbos permite usos metafóricos que se organizam em padrões de metaforização: a metáfora dos verbos AQUA-motion utilizada (I) no movimento executado no ar - AERO-motion e (ii) executada no domínio abstracto (em domínios tais como, por exemplo, abundância, arte, política, economia, finanças, etc.). Assim, podemos navegar através da multidão ouflutuamos a dançar ou, então, nadamos em dinheiro ou enfrentamos a o curso flutuante da moeda. No presente texto, analisamos os usos metafóricos dos verbos AQUA-motion em Português Europeu, comparando-os com os das línguas tipologicamente diferentes, tal como o Polaco (cf. Prokofjeva's 2007, Batoréo 2009).

Palvras-chave: verbos do tipo AQUA-motion. verbos do tipo AERO-motion. Português Europeu. Tipologia Linguística. Metaforização. Padrões de metaforização em Português Europeu. 


\section{Introdução}

The aim of the present paper is to focus on AQUA-motion metaphorical projection onto (i) AEROmotion and (ii) abstract domains, showing evidence from European Portuguese (EP). Very regular wellstructured metaphorical processes will be confirmed in the prototypical contexts centered on AQUA-motion verbs 'nadar' (swim), 'navegar' (navigate) and 'flutuar' (float) expressing smooth movement of gliding or flowing where the ground is no longer of a liquid type, referring either (i) to physical movement in the air/space, i.e., AERO-motion, or (ii) to different abstract domains, such as mental states, social life, politics, financial activity, etc.

In our previous studies on AQUA-motion (Batoréo 2007, 2008 and 2009) we presented some parameters of the AQUA-motion domain in European Portuguese in contrast with other typologically different languages (such as Polish). By Motion events we understand here the movement or location of one entity, the Figure, situated with respect to another entity, the reference object, the Ground (Talmy, 2000: 25). The specifics of the Figure and the Ground, as well as the Manner in which the motion is executed or the Path it follows play a major role in the conceptualisation and linguistic coding of the Motion event. As a number of studies showed in recent decades (cf. Talmy, 1985, 2000 and Newman 1997, 2000) languages may differ in a predictable way not only in grammar but also in lexicon, which means that the differences shown in their lexicon are not arbitrary (cf. Atkins \& Fillmore 2001; Koch 2001; Filipovic \& Jaszczolt 2012; Vulchanova \& Van der Zee 2013).

In our studies the semantic field of Motion is examined in particular and its specific area of being in Motion in liquid medium - AQUA-motion domain - is focused upon, following the theoretical background of a series of studies by Majsak \& Rahilina 2003 and 2007, Lander Majsak \& Rahilina [2005] 2008, 2012 and 2013, and by Divjak \& Lemmens, 2007. According to these studies developed in various typologically different languages, and confirmed for Portuguese (Batoréo 2007, 2008 and Batoréo et al. 2007), the basic parameters within the AQUA-motion domain are of a conceptual and semantic character envolving:

(i) nature of a moving Figure: humans, vessels and/or animals;

(ii) nature of Ground: prototypically water in AQUA-motion or any other liquid, and air in AERO-motion metaphorical projections, and abstract domains, as for instance social life or politics;

(iii) nature of Motion and Manner in which Motion is focused: passive vs. active (self-propelled vs. driven by current), controlled vs uncontrolled, directed vs. non-directed, contained vs. noncontained (within the liquid or on its surface).

In the present study we will first focus on the actualized revision of the literature of AQUA-motion domain (section 2) presenting: (i) 2.1. Motion events and Ground typology (section 2.1.), (ii) basic AQUAmotion typology (section 2.2.) (iii) AQUA-motion systems (section 2.3.), and (iv) extended version of basic AQUA-motion typology (section 2.4.). Section 3 will focus on metaphorization processes that origin in AQUA-motion domain and are projected onto (i) AERO-motion domain (section 3.1.), and (ii) different abstract domains (section 3.2.). At the end some conclusions will be presented in section 4.

\section{AQUA-motion domain revisited}

\subsection{Motion events and typologies}

The notion of predictability of languages not only in grammar but also in lexicon was first defended for Motion events by Leonard Talmy by postulating lexicalization patterns (Talmy, 1985; cf. Batoréo 2000). Talmy's typological distinction between verbframed languages and satellite-framed languages shows that different languages organize their lexical architecture in different patterns, which is predictable and not arbitrary, and also structured. Thus verb- 
framed languages (as the Romance) frame typically the Path in the verb, with Manner or Cause optionally expressed in a satellite, whereas satellite-framed languages (such as the Germanic or Slavonic languages) express the core schema of Motion and Path in a satellite leaving the verb free to express Manner or Cause. This means that when in Portuguese (which is a Romance language) we want to say that John swam across the river we have to structure the utterance by referring that he crossed the river swimming (a strategy which is strange and/or unacceptable in English, which is a Germanic language). Thus a Portuguese speaker will say 'João atravessou o rio a nado/ a nadar/ nadando' (John crossed the river swimming), framing the Path in the verb cross ('atravessou'), and leaving the Manner to be expressed (optionally) by a satellite 'swimming' (a nado/ a nadar/ nadando). In other words, in typologically different languages verbs may typically conflate two different concepts, either as [Motion + Path] or as [Motion + Manner] (Talmy 1985, 2000). The subcategorization of Motion can be suggested, focusing on the presence per se of Motion or Location: (i) translational Motion, where an object's basic location shifts from one point to another in space, (ii) self-contained Motion, as in oscillation, rotation, expansion, and local wander, and (iii) stationary Motion, as in the case of location verbs (cf. Talmy 2000, II: 35).

Within the range of Motion (and mostly translational Motion) three basic domains can be distinguished (cf. Divjak \& Lemmens, 2007) on the basis of the types of Ground: (i) AQUA-motion with respect to water (or, by extension, to liquids in general) as in verbs swim, sail or float, (ii) AEROmotion, with respect to air, as in fly or hover, and (iii) TERRA-motion with respect to earth, as in walk, crawl or drive.

It should be noted that this distinction is pitched at a relatively high level of abstraction distinguishing as ground types air, earth and water [...]. Obviously, not all languages carve up the ground-space in this way: some may make no distinction at all, others may conflate two (e. g., air and water) and there may even be languages that impose more fine-grained distinctions. (DIVJAK \& LEMMENS, 2007, p. 152).

What is extremely interesting in the proposal above in which the distinction of different types of Motion is made on the basis of different types of abstracted Ground is that it results mostly in different types of verbs that express Manner, even in verbframed languages like Portuguese, that prototypically are expected to frame the Path in the verb, leaving Manner or Cause to be optionally expressed in a satellite. The present study will give language-in-use evidence to prove this hypothesis in EP; although considered a verb-framed language, Portuguese uses many verbs that conflate Motion and Manner, a strategy typical of satellite-framed languages (like those of the Germanic and Slavonic families), which we hypothesized happens in a predictible and structured way. Crossing and exploring different typologies may give us more insight about what we can consider real "lexicalization patterns" that structure Portuguese.

\subsection{Basic AQUA-motion typology}

Using relevant information on AQUA-motion expression in more than 40 languages from different typological families, Majsak and Rahilina (2003, 2007) and Lander, Majsak and Rahilina ([2005] 2008, 2012, 2013) suggest the most basic distinction in the AQUAmotion domain in three domains: (i) SWIMMING, (ii) SAILING, and (iii) FLOATING (cf. also Arad 2007). Since 2012 in Lander et al. $(2012,2013)$ the FLOATING domain has given ground to two domains, FLOATING and DRIFTING, but no basic conceptual distinction was observed in preferring four domains to three. The authors of the basic tripartition argue that it manifests itself more or less consistently in most languages of the sample the authors used by means of lexical oppositions and constraints on interpretation arising in the corresponding contexts. This widespread occurrence is interpreted by the authors as "not arbitrary" and it is postulated that it "perhaps mirrors universal tendencies in conceptualization of AQUA-motion" (Majsak \& Rahilina, 2007, p. 17) 
All in all, we believe that the tripartition proposed here does have an objective nature. Rakhilina (2007) suggests that this distinction aptly manifests itself not only in the organization of aqua-system proper, but also in metaphorical extensions found for different kinds of verbs (different domains have different ranges of metaphorical extensions). Given this, the typology of aqua-motion systems offered in this paper may bring to light not only cross-linguistic similarities but also non-trivial regularities in the areas which earlier were thought to be largely unpredictable.

Finally, the very principle of the cross-linguistic comparison of lexical systems based on the distinguishing between various (sub)domains seems to be promising and may become a useful tool for discovering the laws that govern lexical structures of languages. (LANDER et al. [2005] 2008, p. 18-19)

The SWIMMING domain is typically associated with self-propelled motion of an animate figure, which presupposes much control and agentivity, as in 'swim' and 'plunge', in English, and 'nadar' (swim), in Portuguese, as in the above exemple 'João atravessou o rio a nado/ a nadar/ nadando'. The most common use of 'nadar' can be interpreted as either directed or non-directed, and only specific contextualization will allow either clearly directionoriented interpretations or non-oriented ones. In the SWIMMING domain there can also be distinguished a sub-class of the "merge" verbs - in EP 'imergir' (immerse), 'emergir' (emerge), 'submergir' (submerge) - as in 'emergir da multidão' (come out/ emerge out of the crowd), both in literal and in metaphoric meaning, 'classe emergente' (an emergent class, referring to nouveau-riche people) or 'banho de imersão' (tub immersed bath as opposed to shower)

The SAILING domain is typically associated with motion of vessels or people aboard, as in 'sail and 'row', in English, which presupposes some agentivity, yet this is not always the agentivity of the Figure. In Portuguese we have the main verb 'navegar' (navigate) form: 'nave' (vessel), but also many other highly motivated terms as in 'velejar'/ 'andar à vela'l 'fazer vela', from: 'vela' (sail)), 'marear' from: 'mar' (sea), 'fazer surf'l 'surfar' (to surf), 'remar' (to row), and 'vogar', 'singrar' (to sail). It is curious to observe (cf. Batoréo et al. 2007) that in EP we have verbs and (nearly) synonymous verbal periphrastic expressions as in the case of surfing or sailing (see examples above), and their usage is context and register dependent. Some of the EP verbs of the SAILING domain, such as 'marear' (which is a false cognate of its Spanish homonym) 'vogar' or 'singrar' (to sail) have strong restriction of usage in modern EP: they are either cristalized in fixed expressions (as in 'carta de marear'l 'carta náutica', which refers to a navigation map, 'arte de bem navegar'l'arte de bem marear' (navigation art) or 'mestres de marear' (navigation masters)) or even quite obsolete in their literal sense, maintaing nowadays only the metaphoric meaning, as can be observed in the case of 'singrar na vida' (sail in life) meaning succeed in life over the waves of misfortune.

An interesting general feature of the SAILING verbs is their capacity to be used both with animate (mainly human) and inanimate figures (namely vessels), which can be thought of as an instance of the well-known metonymical shift container > content, as can be observed in EP: 'Os marinheiros navegam nos mares do sul (Sailors sail in the seas of the south) or 'Os barcos navegam nos mares do sul' (Ships sail in the seas of the south).

On the other hand, the FLOATING domain reflects the situation of passive, uncontrolled and nonagentive movement in liquid, both within the liquid and on its surface, as in 'flow' and 'drift', in English, and 'flutuar', 'boiar', 'andar à deriva', in Portuguese: 'Os peixes/ os corpos mortos flutuam/ boiam no rio' (Fish/ corpses float in the river). While in many contexts 'flutuar' and 'boiar' seem to be synonymous and easily interchanged, there are some conceptual restrictions that differentiate them: while 'boiar' implies movement on the surface of the water, 'flutuar' has larger scope, implying the movement both on the suface and within the liquid itself, the Figure being submerged, which 'boiar' does not allow, implying the situation of containment. So in the case of 'o bebé flutua no ventre materno' (the baby floats in his/ her mother's womb) we can only use the verb 'flutuar' and not 'boiar', as the movement referred to is within the liquid and not on its surface. When drifting is referred to, an analytical expression 'ficar à deriva' (to stay 
adrift) is used, both literally and metaphorically: 'Depois do acidente a jangada ficou à derival o homem ficou à deriva durante três dias' (After the accident the raft/ the man drifted/ stayed adrift for three days). Some other FLOATING verbs like 'sobrenadar' (over + swim) or 'sobreaguar' (over + water + Inf) that are still mentioned in some (lexicographic) studies on Portuguese AQUA-motion verbs (cf. Majsak 2007) are not confirmed in present day EP usage.

\subsection{Middle, rich and poor AQUA-motion systems}

According to the studies of AQUA-motion domain (cf. Majsak \& Rahilina 2007), languages can generally be divided into middle, rich and poor AQUAmotion systems. A system is characterized as middle if it distinguishes between the three types of AQUAmotion verbs as discussed in section (2.2.) but does not display any additional opositions, which is for example the case of Persian, Tamil and Maninka. On the other hand, there are languages whose AQUAmotion lexicon is significantly distinct and much more complex and rich than the middle ones, as happens in standard Indonesian. According to the same authors, Indonesian AQUA-motion verbs can easily be classified into three main groups that correspond to the main domains but then are richly specified. In the Indonesian SWIMMING domain there is a neutral verb corresponding to 'swim' and a specific one meaning 'plunge', 'swim under the water', etc. In the Indonesian SAILING domain there is a neutral verb corresponing to 'sair, and then some means-specified ones ('sail on a ship', 'sail on a boat', 'sail on a raft', 'row'), and place-specified ones ('go in a lake', 'go seaward' or 'go in a channel'). In the Indonesian FLOATING domain there is a possibility of strong dynamicity ('flow with the current') and semidynamicity ('float', 'drift about (on water)', 'swing to and fro', and so on). On the other hand, in a poor AQUA-motion system the distinction between the three types of verbs is obscured, made peripheral or neutralized, which is the situation observed in many Slavic languages (e.g.
Russian or Polish), where a single root supplies all three domains (cf. Batoréo 2009). The verbs are morphologically related and differ roughly in the iterativity and/or directedness of the process irrespectively of the domain. Thus in Polish we say 'Człowiek/ łodka/ kloc drzewa płynie do brzegu' ( $A$ man/ a boat / a log swims/sails/floats towards the bank' and 'Człowiek/ łodka/ kloc drzewa pływa przy brzegu' ( $A$ man/ a boat / a log is moving to and fro not far from the bank), where the only verb 'pływać'l 'płynąć' (swim, float, sail), with alternative forms of the same verb that correspond to the aspectual opposition Imperfective vs. Perfective of the general Polish AQUA-motion verb, neutralizes all the oppositions observed in other both middle and rich AQUA-motion systems.

In comparison with other AQUA-motion systems, the European Portuguese AQUA-motion lexicon (cf. Batoréo 2007, Batoréo et al. 2007, Majsak 2007) is richer than in the middle systems but not as complex as the Indonesian rich system described above. European Portuguese AQUA-motion verbs can be easily classified into three main groups, as shown above, but then richly specified only in some of them, as in the SAILING domain, due to Portuguese cultural and historic sea tradition.

\subsection{Extended AQUA-motion typology}

On the basis of the study of AQUA-motion verbs in Dutch (Divjak \& Lemmens, 2007) the authors proposed an extension of the basic typology defended by Majsak and Rahilina $(2003,2007)$ and Lander, Majsak \& Rahilina ([2005] 2008, 2013) and characterized above in section 2.2. Divjak \& Lemmens (2007:155, table I) postulate that the basic typology of three systems (i) SWIMMING, (ii) SAILING and (iii) FLOATING should be extended, taking into consideration four more classes of AQUA-motion domains: (iv) CONTAINMENT - movement within the water, as in English 'hover', 'float'; (v) MERSION up/down movement up/down of water, as in English 'dive', 'sink'), (vi) SPLATTER - movement which makes water move as well, as in English 'splash', (vii) 
FLOW - movement of water itself, as in English 'stream', 'flow', 'run'.

Contrary to what might have been suggested in our 2007 study (Batoréo 2007), we think now that the EP data do not show global relevance of these new conceptual proposals as separate AQUA-motion systems in the case of Portuguese, though this typological proposal can in fact be illustrated in other, typologically different languages (see FLOW domain in Portuguese and Polish discussed in Batoréo 2009).

Out of the four more recent domains postulated in Divjak \& Lemmens (2007) only the MERSION domain referring to a down/up movement into and within water/liquid seems to be richly represented in Portuguese by the verbs that have already been taken into consideration and discussed here as the "merge" class of verbs in the SWIMMING domain of the basic proposal (see section 2.2.). Other MERSION domain EP verbs such as 'inundar(-se)' (to dive, to flood), 'afogar(-se)' (to drown), 'afundar(-se)' (to sink), and 'alagar' (to flood) are commonly used (both literally and metaphorically), as illustrated in the following examples: 'Gradualmente, inundou os campos, alagou cidades e aldeias e destruiu casas de habitação.' (It gradually inundated/flooded the fields, swept into towns and villages and destroyed human dwellings.), and especially in (semi-)fixed expressions: 'afogar-se no seu próprio sange, vómito' (to drown in one's blood, vomit), 'afogar-se em lágrimas' (to drown in tears), 'afundar-se em dívidas' (to sink into debt').

As for the SPLATTER proposal, the area is not richly represented in Portuguese; specific SPLATTER verbs are, for example, 'chapinhar' (to splash, slosh) formed from 'chapa' (sheet, plate, badge) or 'patinhar' (moving water with feet, to paddle, slip, slosh) formed from 'pata' (foot of animals, paw), as illustrated in the following exemple: 'Deviam ter visto o Blake, a chapinhar na água gelada em cuecas.' (You should have seen Blake, sloshing around in the freezing cold water in his underpants.). Some other SPLATTER verbs are also used in more restricted contexts as 'esguichar' (to squirt), 'borrifar' (to sprinkle, moisten), 'respingar' (to sprinkle) or semantic extensions of non strictly AQUA-motion verbs as 'espirrar' (to sneeze).
As far as other proposalas are concerned, the CONTAINMENT domain with the floating/ hovering movement within water is rendered in Portuguese by the FLOATING verb 'flutuar', of a larger scope, when compared to a more restricted surface 'boiar' (see above, in section 2.3.).

As for the FLOW proposal, it is an extremely interesting domain referring to movement of water itself, as in English 'to stream', 'to flow'or 'to run'. Though there is a specific verb in Portuguese that expresses this movement 'fluir' (to flow, course, stream), as in 'deixa fluir o desconhecido' (let flow the unknown) its usage is scarce and restricted to mostly metaphorical uses as shown above. Curiously, in the case of FLOW domain, the most common verbs used in Portuguese are non-AQUA-motion verbs 'correr' (run) - a strategy that is also used in English - and other derivated verbs such as 'escorrer' (wash off/ out/ away, run out / away) and 'decorrer' (happen, take place, run, derive), as in: 'Há uma enorme quantidade de água a escorrer da cúpula.' (The dome has an incredible amount of water that washes off of it) or 'Esse diálogo deverá decorrer numa base recíproca e não-discriminatória.' (This dialogue should take place on a reciprocal and non-discriminatory basis.) The frequent "run verbs" 'correr', 'escorrer' and 'decorrer' will be discussed further on in metaphorical contexts in section 3 (see also a thorough discussion on FLOW verbs in Portuguese and Polish in Batoréo 2009, cf. Prokofjeva 2007).

\section{Metaphorical contexts and uses: AERO-motion and abstract movement}

As stressed in the field literature, all the AQUAmotion verbs allow metaphorical projection, though its realization is done in different degrees in different contexts. In Portuguese, even verbs which have become rather obsolete in literal meaning maintain metaphoric ones as the main meaning still in use, as happens, for example, in the case of 'singrar' (sail against the waves) or 'fluir' (flow) discussed above in section (2.4.), which shows that the tendency to 
metaphorize is very strong, even if some basic, literal uses fade away or disappear with time.

In general, the key to the metaphorization can be the Ground no longer being of a liquid type and the projection being realized (i) either onto the AEROmotion (e.g. navigating through a crowd), discussed below in section 3.1. or (ii) onto an abstract domain (e.g. swimming in money, floating currency), discussed bellow in section (3.2.).

It is curious to observe that in general, in poor AQUA-motion systems (as in Slavonic Languages) the basic AQUA-motion aspectual pairs of verb(s) such as 'plyt"/ 'plavat" in Russian or 'pływać'/ 'płynąć' in Polish - can be extended metaphorically to refer to almost any smooth movement, gliding or flowing in the air or in an abstract Ground, describing the smooth motion of clouds or airplanes in the sky, the flow of a crowd of people in the street, of a couple dancing or of music across a ballroom, and even the flow of the course of currency (cf. Batoréo 2009, for Polish). In translation this general AQUA-motion verb of a poor system can be rendered by different AQUA-motion verbs from SWIMMING, FLOATING or SAILING domains (exs. $1 \mathrm{a}$ and $\mathrm{b} ; 2 \mathrm{a}$ and $\mathrm{b}$ below) both in Portuguese and in English.

(1) (a) (PI) 'Pani K. płynęła w walcu.' Mrs. K. swam/ was swimming in a waltz.

(b) (EP) 'A senhora K. flutuava a valsar/ quando valsava.'

Mrs. K. floated/ was floating in a waltz.

(2) (a) (PI) 'Wysoko nad lasami płynęły wiosenne obłoki.'

Some spring clouds swam/were swimming above the forest.

(b) (EP) 'Lá no alto, por cima dos bosques, navegavam/flutuavam as nuvens primaveris.'

Some spring clouds sailed/were sailing above the forest floated/were floating.

It is interesting to observe that in European Portuguese different AQUA-motion verbs show different degrees of metaphorization. Thus, in the EP AQUA-motion corpus gathered from Linguateca (cf.
Batoréo et al. 2007; Casadinho 2007) we analyzed nearly seven thousand usage occurences of AQUAmotion verbs, and separated almost 6700 occurrences of the nuclear verbs of SWIMMING, SAILING and FLOATING domains: 3260 occurrences (49\%) of 'nadar' (swim), 2551 (38 \%) of 'navegar' (sail) and 887 (13\%) of 'flutuar' (float). Only approximately four per cent of the remaining occurences refer to other non-nuclear verbs, as, for instance, 'singrar' (sail) (151 contexts found) or 'marear' (sail) (35 occurrences).

Though 'nadar' (swim) is the most representative verb in our language-in-use corpus sample with nearly half of all the occurrences, it happens to be the least metaphorized, with only five per cent (159 occurrences) of metaphoric usages. On the other hand, the least representative of the three nuclear verbs 'flutuar' (float) with less than one thousand occurences, shows the highest degree of metaphorization with nearly sixty eight percent of metaphors (584 occurrences). The verb 'navegar' (sail) also fairly representative in our corpus shows only one third of metaphorizations (842 occurences). In the least frequent group, two verbs from the SAILING domain show different degrees of metaphorization: 'singrar'(sail) is highly metaphorical (with more than ninety per cent of metaphorical uses), whereas 'marear' (sail) shows only six per cent of metaphors used in the corpus.

The quantitative results presented above show that the distribution of verbs in AQUA-motion domains, on one hand, and metaphoric uses observed in each verb, on the other, are not closely related and are not easy to forsee, as they depend on different factors related either to aspects of language usage (such as, for example, lexicalization patterns or fixedness of constructions), and also cultural ones, such as proverbs and other culturally vehicled texts (like poems, song lyrics, slogans and advertisments) that are frequently used in everyday language. They also depend on sociolinguistic characteristics of the speaking community, its history and tradition (for example, having or not a historic sailing tradition). 
The AQUA-motion metaphors found in our languagein-use corpus can be devided in two basic groups: (i) AERO-motion domain (section 3.1.), and (ii) different abstract domains (section 3.2.).

\subsection{AERO-motion metaphors}

In the case of AERO-motion metaphors we can distinguish four different patterns of projection of AQUA-motion domain onto Motion in the air. In what follows we present typical examples of each one of the metaphorization patterns, some being reinforced by an original occurrence with an extension code from the Linguateca corpus in an (a) line (and subsequent ones) (cf. exemples 3 - 12 below).

The first AERO-motion pattern refers to smooth movement, gliding or flowing in the air and in space. Nuclear verbs from all the three types of AQUAmotion domain are used (exemples $3-5$ ).

(3) 'Nuvens macias nadam através do céu azul' Soft clouds move in the blue sky.

(4) 'A bandeira flutua no ar.' A flag floats in the air.

(4a) 'Só a palavra desnorte servia ontem ao Zaire, em cuja segunda cidade, Lubumbashi, já flutua a bandeira dos rebeldes'. (Ext. 17286)

(5) ' O astronauta flutua no espaço.' An astronaut moves in space.

(5a) 'O astronauta Mike Foale flutua no espaço, centenas de quilómetros acima da superfície da terra, durante o passeio espacial de quase cinco horas do lado de fora do vaivém Discovery'. (Ext. 477724)

(5b) 'O laser será apontado para Terra durante oito dias consecutivos, devendo para isso o Discovery navegar durante esse tempo com as portas do seu porão abertas de par em par.' [Ext. 252767 (clt-soc, 94b)]

(5c) 'Por 40 dólares à hora, navega nas ondas do ciberespaço para outras pessoas com dificuldades de entender aquele espaço virtual'. [Ext. 219301 (clt-soc, 95a)]
The second pattern refers to a situation in which Figure is submerged in a large quantity/abundance of some substance (e.g. clothing, tears, sand), being overwhelmed with this mass abundance, and possibly getting in/out of sight of the observer. The verbs used are 'nadar' (swim) or "navegar' (sail), and the "merge" verbs, as e.g. 'emergir' (emerge) (exemples $6-8)$.

(6) 'Nadar em lágrimas.'

To be drowned in tears.

(6a) 'E nesta luta à parte dos demais, só entre os protótipos, foi o japonês Masuoka (Mitsubishi), quem melhor navegou e se desenvencilhou das areias.'[Ext. 220994 (des, 96a)]

(7) 'Nadar na roupa larga'

To move in loose clothes e.g. after losing weight.

(8) 'Emergir da multidão'. Emerge out of the crowd.

The third pattern refers to a Figure that is unstable, i.e., not fixed in relation to some other Ground, and the verb used is 'flutuar' (float) (example 9).

(9) 'Chão/ pavimento/ revestimento/ soalho flutuante'. durable.

Walking floor, not nailed and less

The forth pattern is used in FLOW domain contexts. As mentioned in section 2, in the FLOW domain Portuguese does not use prototipically any AQUA-motion verbs (cf. Batoréo 2009) but it rather chooses 'correr' (to run) or its derivated forms 'escorrer' (to run off, to wash away) and 'decorrer' (to take place, happen) - interchanging them sometimes with 'flutuar' (float), 'navegar' (sail) or some general motion verbs such as 'andar' (go, walk), 'passar' (pass) or deictic 'ir' (go) and 'vir' (come). The metaphors used in this case have to do with movement in the air of Figure represented for example by clouds, perfume or a great amount of people (examples $10-12$ ). 
(10) 'Havia silêncio no mar; flutuava uma neblina azulada e transparente.'

There was silence in the sea; blue and transparent fog floated over.

(11) 'Das ondas âmbar do cabelo vinha/ flutuava/ despreendia-se/ soltava-se/ emanava um perfume embriagante.'

From amber waves of hair some inebriating scent was coming.

(12) 'Pela entrada principal corria/ vinhal passava ininterruptamente

uma torrente de gente.'

Through the main entrance continuously passed a stream of people.'

\subsection{Abstract metaphors}

In the case of abstract metaphors we can distinguish five different patterns of projection of AQUA-motion domain onto Motion in the abstract Ground. We then present typical examples of each one of the metaphorization patterns, indicating in some cases the original occurrence and extension code from Linguateca corpus in an (a) line (and following ones) (cf. examples $13-30$ below).

The first pattern of abstract metaphors refers to Figure moving skillfully in an abstract domain (politics, social life, art, etc.), struggling against lack of ignorance. The verbs used in this case are 'navegar' (sail), 'nadar' (swim), especially in the construction 'saber nadar' (know how to swim) (examples 13 - 19).

(13) POLITICS:

'O político navega no alto mar'.

A politician moves at sea.

(14 a) Quer levar a oposição a navegar no mar alto, contra um governo que navega à vista de costa.' [Natural Público anotado, versão 3.3., Ext. 21122]

(14) POLITICS/ SOCIAL LIFE:

'Este homem não sabe nadar.'

This man does not know how to swim.

(15) POLITICS/ SOCIAL LIFE:

'Os portugueses nadam no mito como peixes na água.' fish in water.

The Portuguese move in myth like

(16) POLITICS/ SOCIAL LIFE:

'Nadar nas águas melo-antunistas.'
To move in waters/ register of a politician Melo-Antunes.

(16a) '... Sampaio pretendeu dizer aos lisboetas, e ao país, que não abandonava nenhum barco sem que ele tivesse todas as tábuas bem pregadas, para poder flutuar.'

\section{(17) SOCIAL LIFE/ ART: \\ 'Actores que nadam nas águas cómico-sérias.' \\ Actors that move in serious-comic waters/ register.}

(18) ART - SONG LYRICS:

'As pinturas não sabem nadar, iou...' Ancient cave art does not know how to swim $\rightarrow$ meaning: we have to protect the fragile)

$$
\begin{aligned}
& \text { (18a) 'a Constituição } \frac{\text { não }}{\text { sabe nadar, iôu....' (Ext. }} \\
& \text { 226008) } \\
& \text { (18b) '... qualquer coisa } \\
& \text { como - gracejou então - "é } \\
& \text { careta quem partilha } \\
& \text { seringas" ou "quem partilha } \\
& \text { não sabe nadar, iôu".' (Ext. } \\
& \text { 258883) }
\end{aligned}
$$

(19) ART - SONG LYRICS:

'Navegar é preciso....'

Sailing is needed .... $\rightarrow$ meaning: we need to look for new opportunities.

The second pattern of abstract metaphors refers to Figure threading its way through some substance (e. g. crowd), using the verbs 'navegar' (sail), and 'singrar' (sail against the waves) (examples $20-22)$.

(20) POLITICS AND/OR SOCIAL LIFE:

'Navegar em águas turvas.'

To move in nuclear waters.

(20a) Andamos a navegar em águas turvas, sem sabermos quando vamos chegar ao cliente.'.[DiaCLA, anotado v. 1.3, Ext. DLN1626-2]

(21) SOCIAL LIFE:

'Singrar na vida.'

To succeed in life.

(22) SOCIAL LIFE:

'Singrar nos circuitos profissionais.'

To succeed in professional circuits. 
The third pattern of abstract metaphors refers to Figure moving in/on unstable Ground, as in the case of the verb 'flutuar' (float) (examples 23 and 24).

(23) FINANCES/ POLITICS:

'A moeda flutuante'.

Floating currency.

(23a) 'Em Lisboa, o marco/escudo abriu no nível dos 102,05/15 e flutuou numa banda muito apertada, entre 101,10 e 102,15 durante a sessão de ontem.' (Ext. 12612)

(24) SOCIAL LIFE: alugado'

'Flutuar de quarto alugado em quarto

To move on from one rented room to another.

(24a) 'Era, era muito duro esse flutuar ora pelas planícies, ora pelas serras, de quarto alugado em quarto alugado. (Ext. 606173).

The forth pattern of abstract metaphors refers to Figure submerged in a large quantity of Ground (e.g. luxury, richness, dreams, and so on) in the sense of living in abundance /luxury of some other substance, as in the case of the verb 'nadar' (swim) (examples 25 a 27).

(25) ABUNDANCE:

'Nadar em dinheiro/ em riquezal em ouro/ divisas/ notas de mil'.

To swim in money/ richness/ gold/ currency/ one thousand euro notes.

Note: Here the negative context is very frequent to stress lack of abundance/crisis, as in: 'Não nadar em dinheiro' (Not swimming in Money).

(25a) ... sem nadar em dinheiro, a associação apresenta (...) um ponto de vista original .... (Ext. 95762)

(25b) .. é que eu não ando a nadar em notas de mil ... (Ext. 800394)

(25c) ... mas não gosta de nadar em riquezas... (Ext. 900951)

(25d) ... numa Secretaria de Estado que não nadava em dinheiro .. (Ext. 663467)
(26) CRIME:

'Nadar em sangue'.

To swim in blood.

(27) SOCIAL CONTEXT:

'Os emergentes'

Nouveau-riche people

(v) FLOW contexts

As in the AERO-domain above the main verb used in abstract metaphors is 'correr' (run), its derivates and other general Motion verbs that can be interchanged with it (28 to 30 examples):

(28) ART - MUSIC:

'A música corre/ flutual navega/ paira nas/ pelas ruas.'

The music runs through the streets

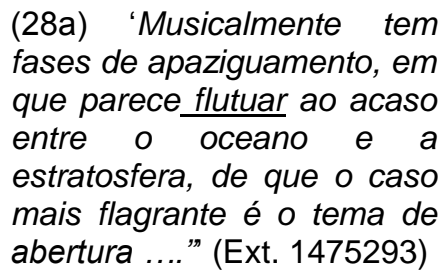

(29) SOCIAL LIFE:

'Dantes corrial vinha um chorrilho de mentiras administrativas e sociais.'

A pack of administrative and social lies was coming.

(30) EXPRESSION OF TIME: Take place, happen, pass, result

(i) 'O dia de hoje correu(-te) bem?' How was it today?

(ii) 'Todos sabemos que os processos que correm pelos tribunais são morosos.'

We all know that the processes run by the courts are slow.

(iii) 'O tempo_corria devagar.' Time ran slowly

(iv) 'A vida decorre/ faz-se com todos os sofrimentos, obrigações, felicidade e tristezas.'

Life goes with all the sufferings, obligations, happiness and sorrows.

(v) 'A reunião decorreu num clima de desconfiança.'

The meeting took place in a climate of distrust.

(vi) 'A força da democracia e da liberdade não vem/ decorre/ resulta da capacidade técnica da defesa, 
não vem/ decorre/ resulta da força do exército. Vem/ decorre/ resulta da sua integridade.'

The strength of democracy and freedom does not come from the technical capacity of the defense or from the army strength, it derives from its integrity.

\section{Conclusions}

The aim of the present study was to focus on AQUA-motion metaphorical projection onto (i) AEROmotion and (ii) abstract domains, showing evidence from EP language-in-usage. Very regular wellstructured metaphorical processes were confirmed in contexts centered on AQUA-motion prototypical verbs 'nadar' (swim), 'navegar' (navigate) and 'flutuar' (float) expressing smooth movement of gliding or flowing where the Ground is no longer of a liquid type, referring either to (i) AERO-motion, i.e., to physical movement in the air/space or (ii) to different abstract domains, such as social life, politics, financial activity, art, expression of time, etc., where the originally liquid Motion is mapped onto non-physical domains.

The present paper was organized in four sections: in section 1 we introduced the study; in section 2 we actualized the revision of the literature of AQUA-motion domain presenting: (i) Motion events and Ground typology, (ii) basic AQUA-motion typology, (iii) AQUA-motion systems, and (iv) extended version of basic AQUA-motion typology; in section 3 we focused on metaphorization processes that originate in the AQUA-motion domain and are projected either onto the AERO-motion domain or onto different abstract domains; finally in section 4 we presented the results of the study and some conclusions.

The main focus of our study was centered on the patterns observed in contexts of metaphorization of AQUA-motion domain. The quantitative results presented from our language-in-use sample gathered in Linguateca show that either verb distribution in AQUA-motion domain or metaphoric uses observed in the case of each verb studied (both nuclear and peripheric) are not closely related and are not easy to forsee. They depend on different facts, both linguistic and non-linguistic, related to (i) aspects of pragmatic language usage (such as lexicalization patterns, fixedness of constructions, and so on), and also (ii) cultural ones, based on culturally vehicled texts (like poems, song lyrics, slogans and advertisments) that are frequently used in everyday language, as well as (iii) sociolinguistic characteristics of the speaking community, its history and tradition.

The AQUA-motion metaphors observed in our language-in-use corpus can be devided in two basic groups: the AERO-motion domain (presented in section 3.1.), and different abstract domains (presented in section 3.2.), each of them showing patterns of metaphorization. There were six patterns observed altogether; some of them were the same in both groups, such as (i) abundance, (ii) lack of stability, and (iii) the FLOW domain pattern. In the case of AERO-motion metaphor (iv) the pattern of smooth movement, gliding or flowing in the air was also presented. On the other hand, in the case of abstract metaphors two more patterns were observed: (v) moving skillfully in order to avoid ignorance, and (vi) threading one's way through some substance.

What our study also shows is that the typology based on different types of Ground (cf. Divjak \& Lemmens 2007) can lead to actual usage of different types of verbs that express Manner (such as 'navegar', 'velejar', 'singrar'), even in verb-framed languages like Portuguese, that prototypically according to the Talmyan theory (Talmy 1985, 2000) are expected to frame the Path in the verb, leaving Manner or Cause to be optionally expressed in a satellite. The present study gives language-in-use evidence that Portuguese, a verb-framed language, uses many verbs that conflate Motion and Manner - a strategy typical of satellite-framed languages - and does it in a predictable and structured way, a hypothesis that we would like to develop in the future. Crossing and exploring different typologies may give us more insight about what we can consider real "lexicalization patterns" that structure Portuguese. 


\section{References}

ARAD, M. (2007). Some aspects of the Hebrew verb saxah (swim). In T.A. Majsak, E. Rahilina (Eds.), Glagoly dviženiâ v vode: leksičeskaâ tipologiâ (AQUA-motion Verbs: Lexical Typology), 498-508. Moskva: Indrik.

ATKINS, S. \& Fillmore, Ch. (2000). Describing polysemy: the case of crawl. In Y. Ravin \& C. Leacock (Eds.), Polysemy: Linguistic and Computational Approaches, 91-110. Oxford: Oxford University Press.

BATORÉO, H. J. (2000). Expressão do Espaço no Português Europeu: Contributo Psicolinguístico para o Estudo da Linguagem $e$ Cognição. (Expression of Space in European Portuguese: Psycholinguistic Contribution to the Study of Language and Cognition). PhD Dissertation (University of Lisbon 1996). Lisboa: Fundação Calouste Gulbenkian.

BATORÉO, H. J. (2008). Cognitive and Lexical Characteristics of Motion in Liquid Medium: AQUA-motion verbs in typologically diferente Languages. Psychology of Language and Communication, 2008, Vol. 12. N. 2, 3-15. ISSN (Print) 12342238, DOI: $\frac{10.2478 / \mathrm{v} 10057-008-0006-}{2009 \text {. }}$

$\underline{x}$, January 2009 . Consulted at: http://www.degruyter.com/view/i/plc.2008.12.i ssue-2/v10057-008-0006-x/v10057-0080006-x.xml (May 2015).

BATORÉO, H. J. (2009). Quando os portugueses correm, os polacos nadam? Domínio de movimento em água (AQUA- motion) em Português Europeu e Polaco: Contribuição para Tipologia Lexical. (When the Portuguese run, the Polish swim? AQUA-motion domain in European Portuguese and Polish: Contribution to Lexical Typology). Diacrítica, 23-1, 2009, Revisto do Centro de Estudos Humanísticos, 55-70.

Consulted http://ceh.ilch.uminho.pt/publicacoes/Diacritic a 23-1.pdf (May 2015)

BATORÉO, H. J., Pires, A., Macedo, I., \& Casadinho, M. (2007). Claro como água! - Contribuição para a tipologia lexical dos verbos de movimento em água AQUA- motion (Clear as water! - Contribution to Lexical Typology of AQUA-motion verbs). Textos seleccionados do XXII Encontro da Associação Portuguesa de Linguística, 2007, 127-140.

CASADINHO, M.M. (2007). Navegar é preciso! Os verbos de movimento AQUA-motion do tipo NAVEGAR. Aspectos linguísticos, cognitivos e traductológicos (AQUA-motion verbs of SAILING type. Linguistic, cognitive and translation aspects). MA dissertation. Lisboa: Universidade Aberta.

FILIPOVIC, L. \& K. Jaszczolt (2012). Space and Time in Languages and Cultures. Linguistic Diversity. Amsterdam and Philadelphia: John Benjamins Publishing Company. Human Cognitive Processing Series.

DIVJAK, D. \& M. Lemmens (2007). Lexical conflation patterns in Dutch AQUA -motion verbs. In T.A. Majsak, E. Rahilina (Eds.), Glagoly dviženiâ $v$ vode: leksičeskaâ tipologia (AQUA-motion Verbs: Lexical Typology), 152-174. Moskva: Indrik.

$\mathrm{KOCH}$, P. (2001). Lexical typology from a cognitive point of view. In M. Haspelmath, E. König, W. Oesterreicher, \& W. Raible (Eds.) (2001). Language Typology and Language Universals: An International Handbook, 1142-1178. Berlin: de Gruyter.

LANDER, Y., Majsak, T. A., \& Rakhilina, E. V. (2005). Motion in a liquid medium (AQUAmotion): towards lexical typology. Paper presented at the 21st Scandinavian Conference of Linguistics, Trondheim, June 1-4, 2005, ms. (updated version from 2008).

LANDER, Y., Majsak, T. A., \& Rakhilina, E. V. (2012). Verbs of aqua-motion: semantic domains and lexical systems. Consulted at: https://www.academia.edu/5911960/2012. Y ury A. Lander Timur A. Maisak and Ekate rina V. Rakhilina. Verbs of aquamotion semantic domains and lexical systems (May 2015).

LANDER, Y., Majsak, T. A., \& Rakhilina, E. V. (2013). Verbs of aqua-motion: semantic domains and lexical systems. In M. Vulchanova \& E. van der Zee \& (Eds.), Motion Encoding in Language and Space. Oxford Linguistics. Oxford: Oxford University Press, 67-83.

Majsak, T. A. (2007). Glagoly peremeŝeniâ v vode v portugal'skom jâzyke (AQUA-motion verbs in Portuguese). In T. A. Majsak, E. V. Rahilina (Eds.), Glagoly dviženiâ v vode: leksičeskaâ tipologia. Moskva: Indrik, 198-230.

MAJSAK, T. A. \& Rahilina, E. V. (2003). Tipologiâ sistem glagol'noj leksiki: dviženie $v$ vode (Typology of verbal lexicon: movement in water). In Grammatičeskie kategorii: ierarhii, svâzi, vzaimodejstvie. Materialy meždunarodnoj naučnoj konferencii, St. Petersburg, 22-24.11.2003 (pp. 89-91). St. Petersburg: Isras.

MAJSAK, E. V. Rahilina (Eds.) (2007). Glagoly dviženiâ v vode: leksičeskaâ tipologia (AQUA-motion Verbs: Lexical Typology), Moskva: Indrik, 305-314. 
NEWMAN, J. (Ed.) (1997). The Linguistics of Giving. Amsterdam: Benjamins.

NEWMAN, J. (Ed.) (2002). The Linguistics of Sitting, Standing, and Lying. Amsterdam: Benjamins.

PROKOFIEVA, I.A. (2007). Peremescenije v vode I peremiscenije vody: glagoly płynąć/ pływać (plyt'/plavat') v polskom jazyke (Movement in water and movemet of water: verbs płynąć/ pływać in Polish). In T. A.

TALMY, L. (1975). Semantics and Syntax of Motion. In J.P. Kimball (Ed.) (1975). Syntax and Semantics. Vol. 4. New York: Academic Press, 181-238.

TALMY, L. (1983). How languag structures space. In H. L. Pick Jr. \& L. P. Acredolo (Eds.) (1983). Spatial orientation: Theory, Research and Application. New York: Plenum Press, 225282.

TALMY, L. (1985). Lexicalisation Patterns: Semantic Structure in Lexical Forms. In T. Shopen (Ed.) (1985). Language Typology and Syntactic Description, Vol. III, Grammatical Categories and the Lexicon. Cambridge: Cambridge University Press, 57-149.

TALMY, L. (2000). Toward a Cognitive Semantics. 2 Vols. Cambridge, MA: The MIT Press.

VULCHANOVA M. \& E. van der Zee \& (Eds.) (2013). Motion Encoding in Language and Space. Oxford Linguistics. Oxford: Oxford University Press. 